DOI: https://doi.org/10.4796o/2303-7431.24.2020.144

UDK: 39:27-055(497.6)

Prethodno priopćenje

Primljen 28. X. 2020.

Prihvaćen 11. IV. 2021.

Vesna Haluga - NiKŠa Sviličić

Sveučilište Sjever, Varaždin/Koprivnica

vehaluga@unin.hr - niksa.svilicic@unin.hr

\title{
ISTRAŽIVANJE SUVREMENE PERCEPCIJE TRADICIJSKE TETOVAŽE NA PRIMJERU TETOVAŽA ŽENA KATOLKINJA IZ BOSNE I HERCEGOVINE
}

\section{Sažetak}

Rad tematizira tetovažu žena katolkinja iz Bosne i Hercegovine, funkciju tetovaže s identitetskoga, vjerskoga i komunikacijskoga aspekta, prvenstveno kao sredstva neverbalne vizualne komunikacije, te njezinu suvremenu percepciju. Tradicijska/vjerska tetovaža na primjeru tetoviranih žena katolkinja iz $\mathrm{BiH}$, na koju se odnosi istraživanje, predstavlja svjesnu tjelesnu modifikaciju koja je povijesno uvjetovana okolinom i kulturom. Istražena je percepcija tradicijske/vjerske tetovaže s obzirom na činjenicu da se više od 9o \% stanovnika Republike Hrvatske deklariralo kao vjernici te je istraženo je li osoba s tetoviranim vjerskim simbolom i vjernik, odnosno je li ta osoba percipirana kao vjernik zbog tetovirana vjerskog simbola/znaka. Rad tematizira i mogućnost doprinosa tradicijske tetovaže procesu nove evangelizacije. Istraživanje je provedeno na uzorku od 310 ispitanika, a ciljevi su: utvrditi percepciju vjerske/tradicijske tetovaže, odnosno utječu li na nju sociodemografske značajke, je li 
opće prihvatljiva ili deklarirani vjernici imaju pozitivniji stav te može li biti komunikacijski simbol deklariranih vjernika.

Ključne riječi: tetovaža; tradicijska/vjerska tetovaža; komunikacija; nova evangelizacija; percepcija

\section{Uvod}

Tetoviranje kao kulturna praksa i tjelesna modifikacija postoji od pamtivijeka. Sanders (2008: 4) kao formu modifikacije navodi modu i stil: „Na najjednostavnijoj razini odjeća i moda su sredstva za simboličko prikazivanje spola, socijalnog statusa, uloge, životnog stila, vrijednosti, osobnih interesa i ostalih elemenata identiteta." Tetovaža je pokretač, posrednik u komunikaciji simbola. Kako navodi Wilson (2008), tetovaže su aktivne, u trenutcima izloženosti one projiciraju simbole drugima. Pojedincima tetovaže ne predstavljaju samo oznaku koja je u tome trenutku bila ideja ili želja, već dio identiteta njih samih. Kao način komuniciranja tetovaža je u istome trenutku i impresivna i ekspresivna. Ona je svjesna tjelesna modifikacija određena socijalnim i kulturnim naslijeđem nositelja.

Tradicijska/vjerska tetovaža koju ovaj rad problematizira, u skladu s navedenim, predstavlja i svjesnu tjelesnu modifikaciju povijesno uvjetovanu okolinom i kulturom. Od prvobitne zaštitne funkcije, preko tradicijsko-običajne, pa sve do forme identitetske identifikacije, tetovaža žena katolkinja u $\mathrm{BiH}$ kroz povijest nije mijenjala vizual nego funkciju uvjetovanu političkim, društvenim, socijalnim i kulturološkim promjenama.

„Tetoviranje žena u $\mathrm{BiH}$ je pojavnost stara više od tisuću godina, a potječe još iz vremena starih Ilirskih plemena koja su živjela na Balkanu“ (Stipčević, 1974: 80). Tradicijsko tetoviranje žena najveću je važnost imalo za vrijeme turske okupacije Bosne i Hercegovine između 1463. i 1878. godine jer je tetoviranje križa kao simbola kršćanstva, pored primarno zaštitne funkcije (sprječavanje odvođenja i silovanja od strane Turaka), imalo i funkciju svjedočenja pripadnosti vjeri/ katoličanstvu. 
Geografski promatrano, običaj tetoviranja žena najviše je bio raširen među Hrvatima u Bosni, na području srednje Bosne te znatno manje $u$ dalmatinskome zaleđu u Republici Hrvatskoj. Fenomen su krajem 19. stoljeća istraživali povjesničar Ćiro Truhelka i engleska putopiskinja Mary Edith Durham. Istraživači su zabilježili 317 motiva koji se javljaju pojedinačno ili u kombinaciji s drugim, a najčešći su motivi križa, križevi s jelicama (jedna grana prema gore, dvije grane prema dolje).

Tetoviranje žena katolkinja čini važnu etnološku cjelinu u kulturno-povijesnome razumijevanju Bosne i Hercegovine u cijelosti, no neosporna je činjenica da je tetoviranje žena katolkinja, poglavito na području srednje Bosne, etnološka posebnost, raritet, jedinstvenost u cijelome svijetu.

Radom će biti istražena i percepcija tradicijske/vjerske tetovaže s obzirom na činjenicu da se velika većina (prema Popisu stanovništva iz 2001. godine više od 90 \% stanovništva $\mathrm{RH}$ ) deklarira kao vjernici. Nastavno, tradicijska tetovaža ima laku dekodaciju svoje simbolike kroz eksplicitnu semantičnost i semiotičnost vlastite ekspresivnosti. Radom će biti istraženo je li osoba s tetoviranim vjerskim simbolom i vjernik, odnosno je li ta osoba percipirana kao vjernik zbog tetovirana vjerskog simbola/znaka.

Nova evangelizacija ${ }^{1}$ sinonim je za duhovni uzlet vjerskoga života lokalnih crkava, upute za put rasuđivanja promjena koje se odnose na kršćanski život u različitim kulturnim i društvenim kontekstima, a može li tetovaža tomu pridonijeti, bit će istraženo. Također, istražit će se i javna percepcija vjerskoga motiva kao novoga oblika sakralne umjetnosti i njezinih drugih oblika te njezine praktične primjene i komunikacijski učinak u istoj. I u ovome dijelu istražit će se pitanje percepcije, ali i same namjere onoga koji stvara, ali i onoga koji konzumira tetovažu kao suvremeni umjetnički izričaj.

Evangelizacija (crkv. lat. evangelizatio, prema grč. $\varepsilon \dot{v} \alpha \gamma \gamma \varepsilon \lambda i \zeta \varepsilon \imath v$ : širiti Evanđelje) - širenje, propovijedanje Evanđelja; propovijedanje kršćanskoga nauka i njegovo prihvaćanje; „evangelizacija", Hrvatska enciklopedija, Leksikografski zavod Miroslav Krleža; <http://www.enciklopedija.hr/Natuknica.aspx?ID=18687>, (10. VIII. 2020.). 


\section{Predmet i područje istraživanja}

Rad tematizira percepciju fenomena tradicijske/vjerske tetovaže na primjeru tetoviranih žena katolkinja iz Bosne i Hercegovine. Budući da je riječ o jedinstvenoj pojavnosti s obzirom na motiv tetovaže i tehniku tetoviranja, tematika interdisciplinarno obuhvaća područje društvenih i humanističkih znanosti, znanstvena polja informacijskih i komunikacijskih znanosti, sociologije, teologije, povijesti, etnologije i antropologije.

Čovjek kao društveno biće oduvijek ima potrebu komunicirati, slati poruke drugim ljudima, od crteža u spiljama, tragova ruku (dlanova), pa sve do iscrtavanja vlastite kože. Kako će poruka koju verbalno, a u slučaju ovoga istraživanja neverbalno, odašilje biti percipirana, primljena, prihvaćena ili odbijena u trenutku početka komunikacije, on ne može znati. Porukom odaslanom preko tetovaže na vidljivome mjestu osoba ostavlja trag svojih vjerovanja, strahova, ideala i sl. Tijelo postaje transmiter slike, a tetovaža ekspresija.

\subsection{Cilj, podciljevi istraživanja i hipoteze}

Cilj je istraživanja utvrditi percepciju vjerske/tradicijske tetovaže. Podciljevi istraživanja su: utvrditi utječu li sociodemografske značajke na percepciju vjerske/tradicijske tetovaže, utvrditi je li vjerska/tradicijska tetovaža opće prihvatljiva ili deklarirani vjernici imaju pozitivniji stav o vjerskoj/tradicijskoj tetovaži, utvrditi je li vjerska tetovaža i komunikacijski simbol iskazivanja vjerskoga identiteta kod osoba koje su se deklarirale kao vjernici.

Slijedom navedenoga predložene su sljedeće hipoteze:

H1: Većini ispitanika prihvatljivo je tetoviranje vjerskih tradicijskih simbola.

H2: Percepcija vjerske/tradicijske tetovaže razlikuje se prema sociodemografskim faktorima (spolu, dobi, mjestu stanovanja).

H3: Deklariranim vjernicima među vjerskim motivima najpoželjniji je motiv hrvatske tradicijske tetovaže.

U postupku razrade hipoteza definirane su zavisne i nezavisne varijable. Nezavisne varijable su sociodemografske značajke (spol, dob, 
stručna sprema, mjesto prebivališta, pripadnost vjeri), a zavisne varijable odnose se na provjeru stavova i percepcije vjerske/tradicijske tetovaže.

\subsection{Ispitanici}

Ispitivanje je provedeno na prigodnome uzorku (uzorku lančane reakcije) od 310 ispitanika $(\mathrm{N}=310)$, različitih sociodemografskih značajki, u razdoblju od tjedan dana (od 13. svibnja 2020. do 22. svibnja 2020. godine). Ispitano je 238 (76,8 \%) osoba ženskoga i 72 (23,2 \%) osobe muškoga spola. Najviše ispitanih osoba, njih 97 (31,3 \%), srednje je životne dobi (između 36 i 45 godina starosti). Budući da je isti broj ispitanih osoba (74 ili po $23,9 \%$ ) od 26 do 35 i od 46 do 55 godina, za ispitivanje hipoteza ispitanici su svrstani u tri kategorije: mlada, srednja i starija životna dob. Glede obrazovanja, najviše ispitanih ima završen fakultet, njih 172 (55,5\%), srednju školu 86 osoba $(27,7 \%)$ te magisterij ili doktorat 52 osobe ili 16,8 \%. Nije bilo ispitanika sa završenom osnovnom školom. Većina ispitanika stanuje u gradu, njih 239 (77,1 \%), a 71 (22,9 \%) živi na selu.

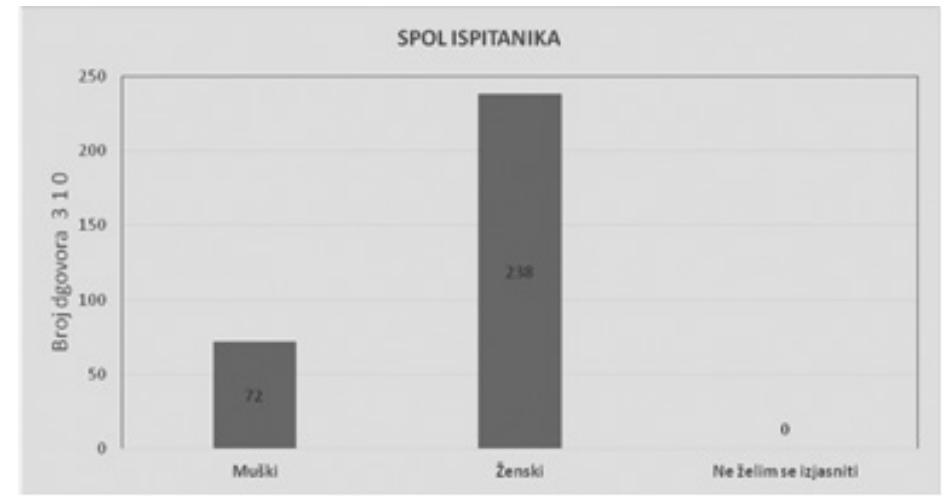

Grafikon 1: Spol ispitanika (izvor: autorica) 


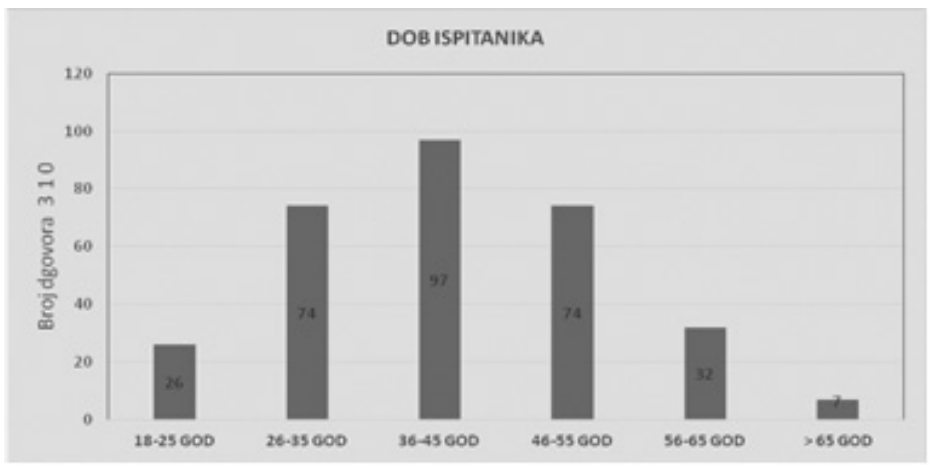

Grafikon 2: Dob ispitanika (izvor: autorica)

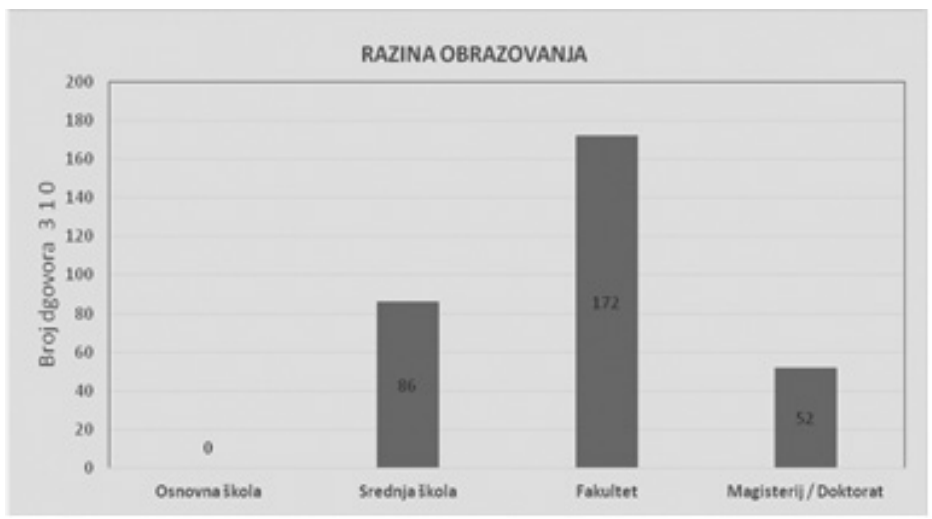

Grafikon 3: Razina obrazovanja (izvor: autorica)

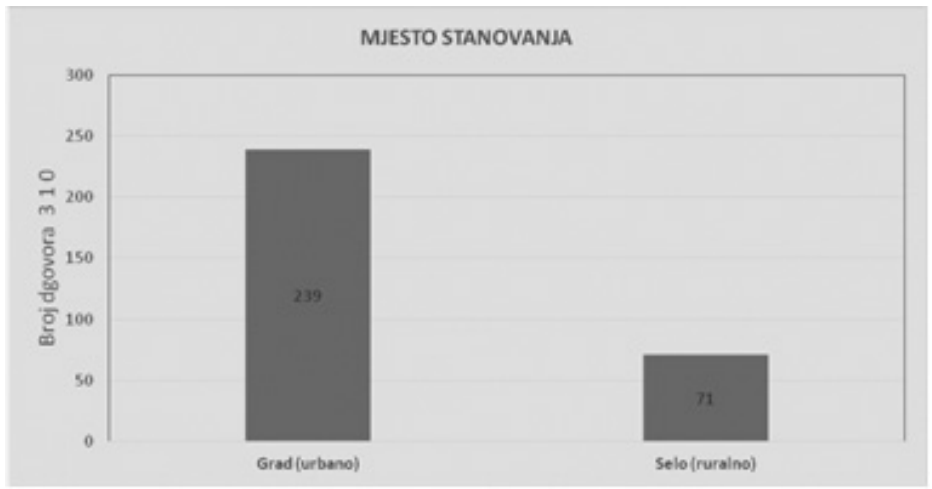

Grafikon 4: Mjesto stanovanja ispitanika/ca (izvor: autorica) 
Kao instrument istraživanja korišten je izvorni upitnik, a anketiranje je bilo potpuno anonimno. Upitnik je podijeljen u dvije cjeline:

1) Sociodemografska pitanja (dob, spol, stručna sprema, mjesto stanovanja).

2) Pitanja kojima se ispituje percepcija tetovaže, vjerske tetovaže i tetoviranja na vidljivome mjestu na tijelu.

\subsection{Analiza rezultata}

Velika većina, odnosno 73,9 \% ispitanika, izjasnila se da su vjernici. Njih 15,8 \% izjasnilo se da nisu vjernici, a 10,3 \% nije se željelo izjasniti. Uspoređujući s podatcima zadnjega popisa stanovništva iz 2011. godine, kada se katolicima izjasnilo 86,28 \%, možemo zaključiti, s obzirom na to da je riječ o uzorku od 310 ispitanika, da je statistički gledano uzorak relevantan za donošenje zaključaka.

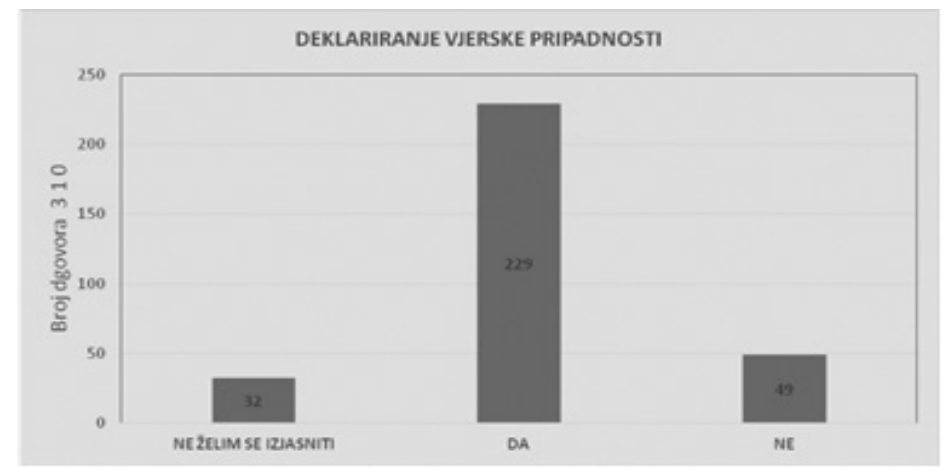

Grafikon 5: Deklariranje vjerske pripadnosti (izvor: autorica)

Čak 64,8 \% ispitanika nije upoznato s pojmom hrvatske tradicijske/ vjerske tetovaže. 


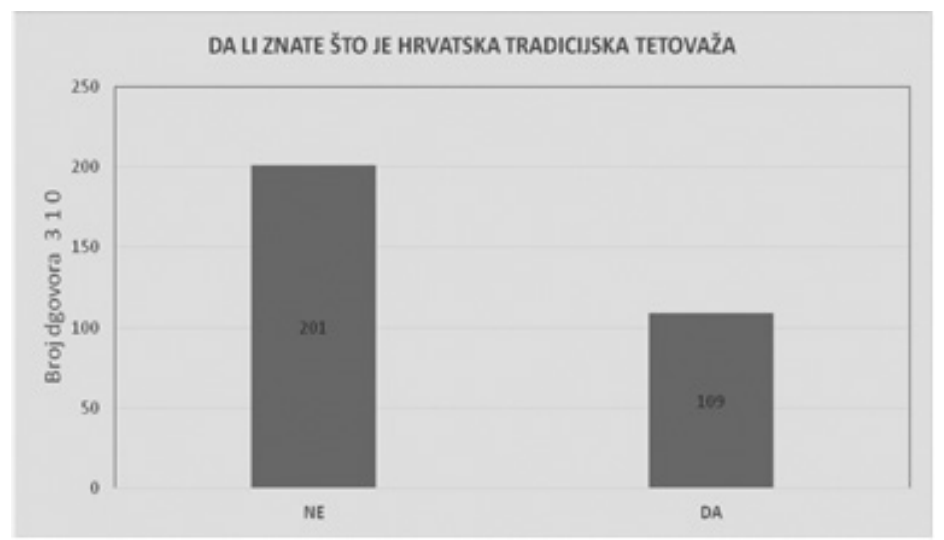

Grafikon 6: Upoznatost s pojmom hrvatska tradicijska/ vjerska tetovaža (izvor: autorica)

Svega 56 (18,1\%) ispitanika ima tetovažu, a većina njih, 179, odnosno $68,3 \%$, ne bi se tetovirala, dok 214 ispitanih (69\%) ne bi dopustilo djetetu da se tetovira.

Bez obzira na nepoznavanje samoga termina hrvatske tradicijske tetovaže, od tri ponuđena motiva (Isus, križ, tradicijska tetovaža) 232 $(74,8 \%)$ ispitanika najpozitivnije je percipiralo motiv tradicijske tetovaže, a njih $182(58,7 \%)$ izjasnilo se kako im se motiv tradicijske tetovaže sviđa više od drugih vjerskih motiva.

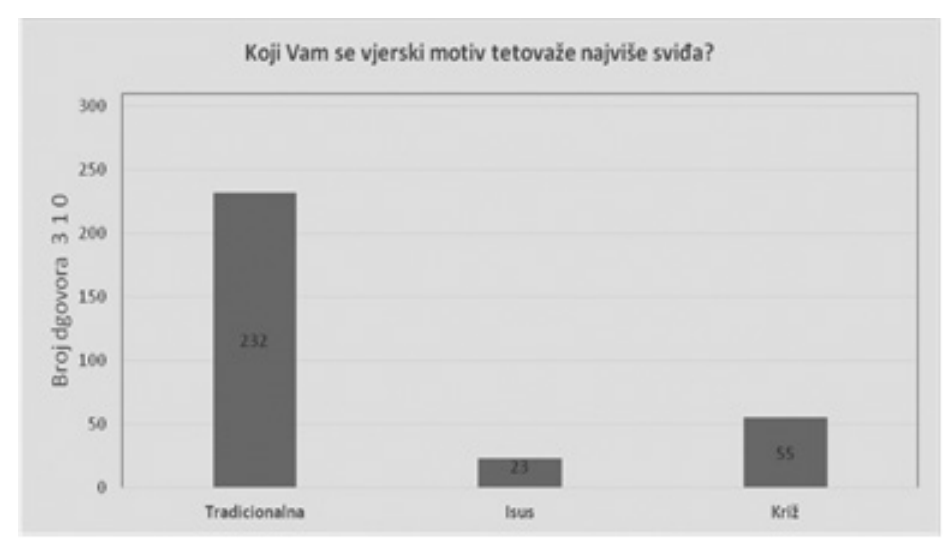

Grafikon 7: Najpoželjniji vjerski motiv tetovaže (izvor: autorica) 


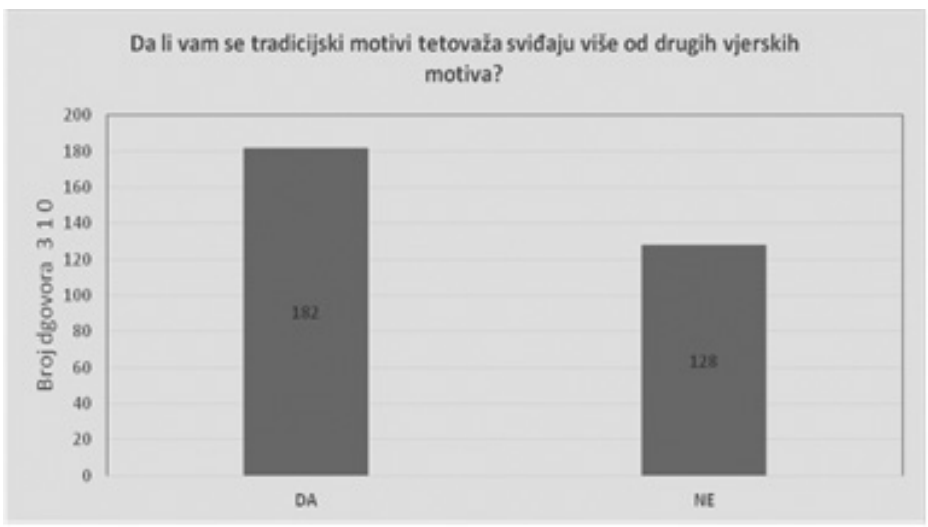

Grafikon 8: Stav o hrvatskome tradicijskom motivu tetovaže u usporedbi s drugim vjerskim motivima (izvor: autorica)

Gotovo svi ispitanici, njih 286 ili 93,2 \%, primjećuju tetovažu na drugim ljudima, ali 188 (60,06 \%) ispitanika nema potrebu saznati više o motivu ili razlozima tetoviranja.

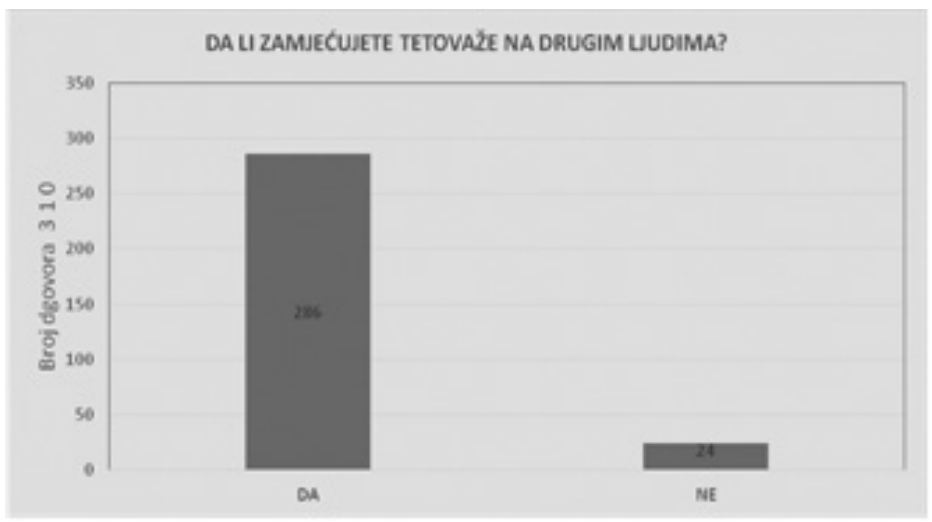

Grafikon 9: Zamjećivanje tetovaže na drugim osobama (izvor: autorica) 


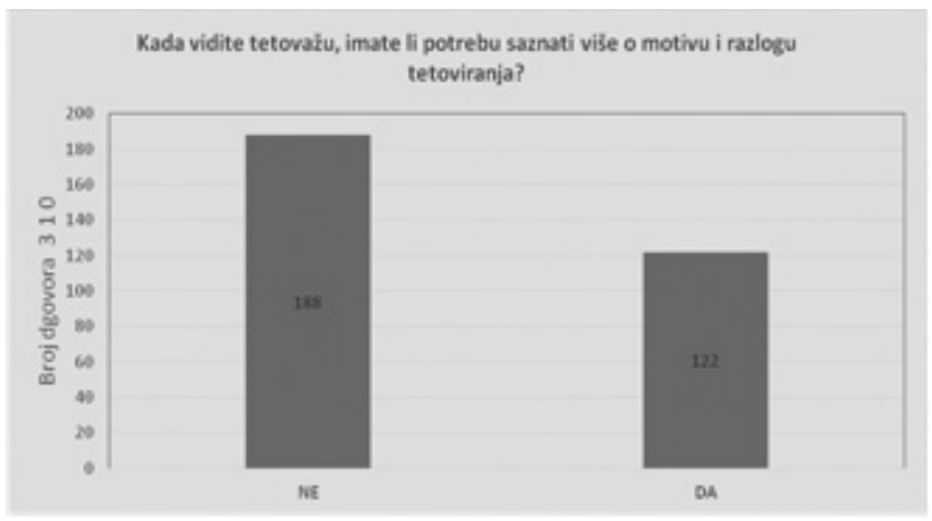

Grafikon 10: Potreba za saznanjem više o motivu i razlozima tetoviranja (izvor: autorica)

Tetoviranje vjerskih simbola na vidljivome mjestu prihvatljivim kod vjernika smatra 47 osoba, odnosno $15,2 \%$. Vjerski motiv privlači veću pozornost ispitanika od drugih motiva kod 51 osobe, odnosno 16,5\% ispitanih. Tetovirani vjerski simboli kod 49 (15,8\%) osoba pobuđuju pozitivan osjećaj. Kod dokazivanja hipoteze (H1) trebaju biti povezane sve značajke s pozitivnom, odnosno s negativnom konotacijom kako bi hipoteza bila potvrđena ili opovrgnuta.

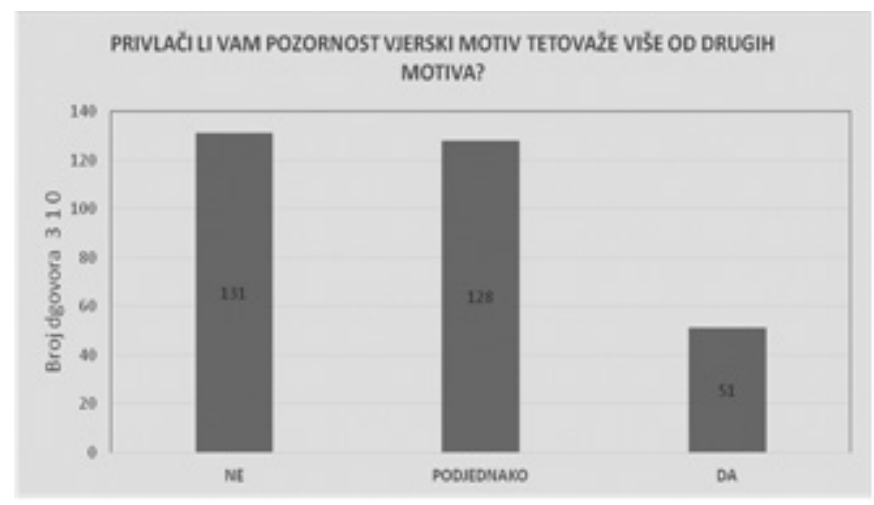

Grafikon 11: Privlačenje pozornosti vjerskoga motiva spram drugih motiva (izvor: autorica) 


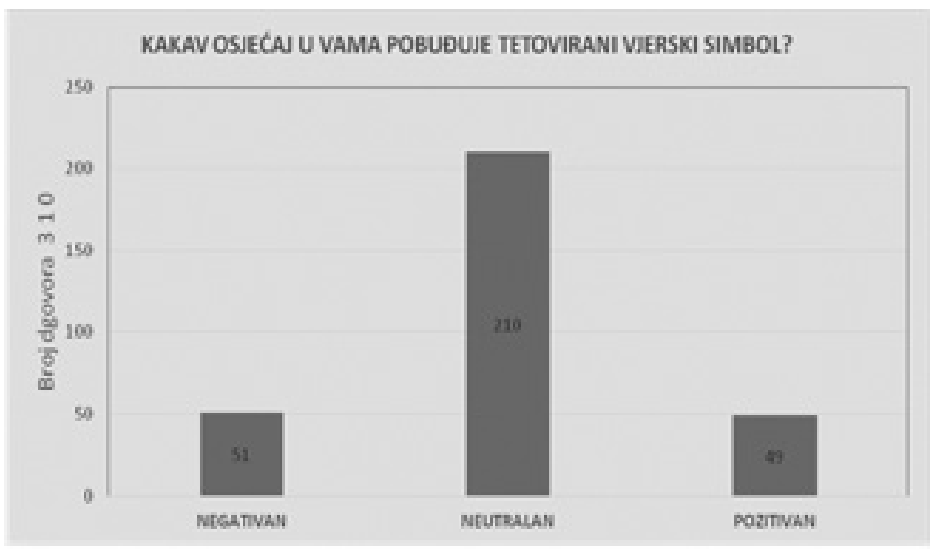

Grafikon 12: 0sjećaj koji pobuđuje tetovirani vjerski simbol

Da je tetovirana vjerska/tradicijska tetovaža dokaz vjerske pripadnosti, smatraju svega 73 osobe ili $23,5 \%$ ispitanika, a da vjernici s tetoviranim vjerskim simbolom imaju veći kredibilitet, smatra svega 8 (2,6 \%) ispitanika. Saznati više o motivu i razlogu tetoviranja potrebu ima $122(39,4 \%)$ ispitanika, a da je vjerska/tradicijska tetovaža novi način evangelizacije, smatra $38(12,3 \%)$ ispitanika. Isto tako, čak $302(97,4 \%)$ ispitanika smatra kako vjernici s tetoviranim vjerskim simbolom nemaju veći kredibilitet.

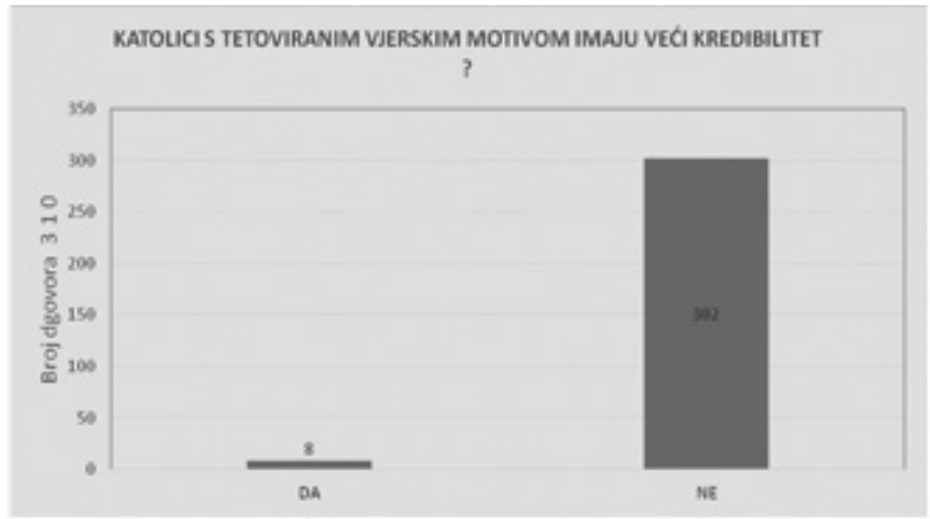

Grafikon 13: Kredibilitet katolika s tetoviranim vjerskim motivom (izvor: autorica) 


\section{Dokazivanje/opovrgavanje hipoteza}

Testiranje hipoteza provedeno je korištenjem statističkoga jezika $R$ ( $R$ Core Team, 2015) te integrirana razvojnog okruženja RStudio (RStudio Team, 2015), preciznije funkcija prop.test() (za z-test za jednu proporciju) i chisq.test() (za test). ${ }^{2}$

Hipoteza H1: Većini ispitanika prihvatljivo je tetoviranje vjerskih tradicijskih simbola

Promatramo pitanje: „Tetoviranje vjerskih simbola na vidljivom mjestu smatrate: neprihvatljivim za vjernike/ce; općenito neprihvatljivim; općenito prihvatljivim; prihvatljivim za vjernike/ce“. Kao prihvatljivo prihvaćamo kategorije: općenito prihvatljivim i prihvatljivim za vjernike/ce. Proveden je z-test za jednu proporciju.

Hipoteze za provedeni test pomoću oznaka možemo zapisati kao: $\mathrm{H}_{\mathrm{o}}: \mathrm{p}=0.50, \mathrm{H}_{1}: \mathrm{p}>0.50$. Hipoteza je testirana na razini statističke značajnosti $\alpha=0,05$.

Tablica1: Proporcija prihvatlivivosti

\begin{tabular}{|l|l|l|l|}
\hline$n$ & $D a$ & Proporcija onih kojima je to prihvatljivo & p-vrijednost \\
\hline 310 & 210 & prihvatljivo=0,68 & $<0.0001$ \\
\hline
\end{tabular}

S obzirom na to da je P-vrijednost manja od izabrane razine statističke značajnosti $\alpha$ (tj. P-vrijednost < o,05), možemo na razini statističke značajnosti o,o5 zaključiti da većina ispitanika smatra kako je tetoviranje vjerskih tradicijskih simbola prihvatljivo, odnosno možemo potvrditi hipotezu H1.

Hipoteza H2: Percepcija vjerske/tradicijske tetovaže razlikuje se prema sociodemografskim značajkama (spolu, dobi, mjestu stanovanja).

Analizirat ćemo rezultate pitanja: „Kakav osjećaj u Vama pobuđuje tetovirani vjerski simbol?” Ponuđeni su odgovori: negativan, neutralan te pozitivan. Pod sociodemografskim faktorima promatramo spol, dob te mjesto stanovanja. Provest ćemo tri testa.

$2 \quad R$ Core Team (2015) „R: A Language and Environment for Statistical Computing“, Vienna: $R$ Foundation for Statistical Computing, <https://www.R-project.org>, RStudio Team (2015) „RStudio: Integrated Development for R“, RStudio, Boston, <http://www.rstudio.com/>. 
1. Razlike po spolu:

Tablica 2: Razlike po spolu

\begin{tabular}{|l|l|l|l|l|}
\hline & Negativan & Neutralan & Pozitivan & Ukupno \\
\hline \multirow{3}{*}{ Muško } & 16 & 41 & 15 & 72 \\
\cline { 2 - 5 } & $22,2 \%$ & $57 \%$ & $20,8 \%$ & \\
\hline \multirow{2}{*}{ Žensko } & 35 & 169 & 34 & 238 \\
\cline { 2 - 5 } & $14,7 \%$ & $71 \%$ & $14,3 \%$ & \\
\hline \multirow{2}{*}{ Ukupno } & 51 & 210 & 49 & 310 \\
\hline
\end{tabular}

Hipoteze su:

Ho: Percepcija vjerske/tradicijske tetovaže ne razlikuje se prema spolu.

H1: Percepcija vjerske/tradicijske tetovaže razlikuje se prema spolu.

Hipoteza je testirana na razini statističke značajnosti $\alpha=0,05$.

$S$ obzirom na to da je P-vrijednost veća od izabrane razine statističke značajnosti $\alpha$ (tj. P-vrijednost $=0.08161>0,05)$, ne možemo na razini statističke značajnosti o,o5 zaključiti da se percepcija vjerske/tradicijske tetovaže razlikuje prema spolu.

2. Razlike po dobi:

Tablica 3: Razlike po dobi

\begin{tabular}{|l|l|l|l|l|}
\hline & Negativan & Neutralan & Pozitivan & Ukupno \\
\hline \multirow{3}{*}{$18-35$} & 18 & 67 & 15 & 100 \\
\cline { 2 - 5 } & $18 \%$ & $67 \%$ & $15 \%$ & \\
\hline \multirow{3}{*}{$35-55$} & 22 & 121 & 28 & 171 \\
\cline { 2 - 5 } & $12,9 \%$ & $70,8 \%$ & $16,3 \%$ & \\
\hline \multirow{3}{*}{$55+$} & 11 & 22 & 6 & 39 \\
\cline { 2 - 5 } & $28,2 \%$ & $56,4 \%$ & $15,4 \%$ & \\
\hline \multirow{2}{*}{ Ukuрno } & 51 & 210 & 49 & 310 \\
\hline
\end{tabular}

Varijabla dob grupirana je u tri kategorije: osobe starosti između 18 i 35 godina, osobe starosti između 35 i 55 godina te osobe starije od 55 godina. 
Hipoteze su:

Ho: Percepcija vjerske/tradicijske tetovaže ne razlikuje se prema dobi.

H1: Percepcija vjerske/tradicijske tetovaže razlikuje se prema dobi.

Hipoteza je testirana na razini statističke značajnosti $\alpha=0,05$.

$S$ obzirom na to da je P-vrijednost veća od izabrane razine statističke značajnosti $\alpha(\mathrm{tj}$. P-vrijednost $=0.2134>0,05)$, ne možemo na razini statističke značajnosti o,o5 zaključiti da se percepcija vjerske/tradicijske tetovaže razlikuje prema dobi ispitanika.

3. Razlike prema mjestu stanovanja:

Tablica 4: Razlike prema mjestu stanovanja

\begin{tabular}{|l|l|l|l|l|}
\hline & Negativan & Neutralan & Pozitivan & Ukupno \\
\hline \multirow{3}{*}{ Grad } & 44 & 157 & 38 & 239 \\
\cline { 2 - 5 } & $18,4 \%$ & $65,7 \%$ & $15,9 \%$ & \\
\hline \multirow{3}{*}{ Selo } & 7 & 53 & 11 & 71 \\
\cline { 2 - 6 } & $9,9 \%$ & $74,6 \%$ & $15,5 \%$ & \\
\hline Ukupno & 51 & 210 & 49 & 310 \\
\hline
\end{tabular}

Hipoteze su:

Ho: Percepcija vjerske/tradicijske tetovaže ne razlikuje se prema mjestu stanovanja.

H1: Percepcija vjerske/tradicijske tetovaže razlikuje se prema mjestu stanovanja.

Hipoteza je testirana na razini statističke značajnosti $\alpha=0,05$.

Kako je P-vrijednost veća od izabrane razine statističke značajnosti $\alpha(\mathrm{tj}$. P-vrijednost $=0.2136>0,05)$, ne možemo na razini statističke značajnosti o,05 zaključiti da se percepcija vjerske/tradicijske tetovaže razlikuje prema mjestu stanovanja.

Iz dobivenih rezultata ne možemo zaključiti kako se percepcija vjerske/tradicijske tetovaže razlikuje prema sociodemografskim značajkama (spolu, dobi, mjestu stanovanja), stoga na temelju provedene statističke analize odbacujemo hipotezu H2: Percepcija vjerske/tradicijske tetovaže razlikuje se prema sociodemografskim značajkama (spolu, dobi, mjestu stanovanja). 
Hipoteza 3: Među tetovažama s vjerskim motivom vjernicima je najpoželjniji motiv tradicijske tetovaže.

Promatramo samo uzorak vjernika. Sada nam je veličina uzorka 229.

Promatramo pitanje: „Sviđaju li Vam se tradicijski motivi više od drugih vjerskih motiva?"

Proveden je z-test za jednu proporciju.

Hipoteze za provedeni test pomoću oznaka možemo zapisati kao: $\mathrm{H}_{\mathrm{o}}$ : $\mathrm{p}=0.5 \mathrm{O}, \mathrm{H}_{1}: \mathrm{p}>0.50$. Hipoteza je testirana na razini statističke značajnosti $\alpha=0,05$.

Tablica 5: Testiranje najpoželjnijega motiva

\begin{tabular}{|l|l|l|l|}
\hline$n$ & Da & $\begin{array}{l}\text { Proporcija vjernika kojima se tradicijski motiv } \\
\text { najpoželjniji }\end{array}$ & p-vrijednost \\
\hline 229 & 210 & $P_{\text {najpožljniji }}=0,55$ & 0,04926 \\
\hline
\end{tabular}

Kako je P-vrijednost manja od izabrane razine statističke značajnosti $\alpha(\mathrm{tj}$. P-vrijednost < o,05), možemo na razini statističke značajnosti o,05 zaključiti kako je vjernicima među tetovažama s vjerskim motivom najpoželjniji motiv tradicijske tetovaže.

Dobivena je P-vrijednost granična, tako da je uzeta neka manja razina statističke značajnosti, npr. $\alpha=0,04$ ili manje. Ne bismo mogli odbaciti nultu hipotezu, stoga potvrđujemo hipotezu $\mathrm{H}_{3}$ : Među tetovažama s vjerskim motivom vjernicima je najpoželjniji motiv tradicijske tetovaže.

\section{Zaključak}

Iz svega navedenoga razvidno je kako je tradicijska/vjerska tetovaža kao motiv pozitivno percipirana te je poglavito među vjernicima najpoželjniji motiv među vjerskim motivima tetovaže. Percepcija tradicijske tetovaže ne razlikuje se prema sociodemografskim značajkama (spolu, dobi, mjestu stanovanja). Istraživanjem je dokazana laka dekodacija simbolike tradicijske tetovaže kroz eksplicitnu semantičnost i semiotičnost vlastite ekspresivnosti.

$\mathrm{Na}$ tragu nove evangelizacije, koja je sinonim za duhovni uzlet vjerskoga života lokalnih crkava te uputa za upravljanje promjenama koje 
se odnose i na komunikacijski aspekt kršćanskoga života u različitim kulturnim i društvenim kontekstima, dokazana je pozitivna uloga vjerske tetovaže u tome diskursu religije. Nadalje, ovo istraživanje otvorilo je nova pitanja te je u budućim istraživanjima potrebno istražiti komunikacijski aspekt javne percepcije vjerskih motiva kao mogući novi oblik sakralne umjetnosti te ulogu vjerske tetovaže u interpersonalnoj i interaktivnoj komunikaciji osoba koje su deklarirani vjernici i onih koji to nisu.

Iz rezultata provedenoga istraživanja moguće je zaključiti kako je tetovaža iznimno snažan vizualni komunikator, općerazumljiv jezik za svaku vrstu poruke koja se želi odaslati, forma - bilo da ju smatramo umjetnošću ili ne, koja zbog osobnosti nema sekundarno tržište, koju nosite sa sobom u grob, a do tada to je umjetnost koja hoda svijetom prenoseći individualnu poruku, stav, emocije i sl., izazivajući primatelje poruke u pozitivnome ili negativnome smislu.

Kada je riječ osobama koje su deklarirani vjernici, treba se čuvati crno-bijeloga gledanja na pojavnost tetoviranja te, kako kaže kardinal Ravasi (2012), govoreći o evangelizaciji novoga doba, treba se truditi duel pretvoriti u dijalog. Zaključno, kao i sa svime u životu, tako i s tetovažama s vjerskim motivom: „Sve što se ne čini po čvrstom uvjerenju grijeh je." $(\operatorname{Rim} 14,23)$

\section{Literatura}

- Ančıć, Nediljko (2007) „Tumačenje znakova vremena - zaboravljena zadaća crkve“, Crkva u svijetu, Katoličko bogoslovni fakultet Sveučilišta u Splitu, Split, god. XLII, br. 2, str. 200 - 226.

- Cvitković, Ivan (2006) Hrvatski identitet u BiH, Hrvati izmedu nacionalnog i građanskog, Synopsis, Zagreb - Sarajevo.

- ČUrČIĆ, VejSIL (1933) „Tetoviranje katolika u srednjoj Bosni“, Napredak - Glasilo hrvatskog kulturnog društva, Sarajevo, god. VIII, br. 6 , str. $71-73$. 
- Drugi Vatikanski koncil-Dokumenti (1986) IV. izdanje, Kršćanska sadašnjost, Zagreb.

- Durham, Mary Edith (2002) Some Tribal Origins, Laws and Custom of the Balkans, George Allen \& Unwin, London.

- DžAjA, SRećKo (2010) „Bosna i Hercegovina kao politička kategorija kroz povijest", Status- magazin za političku kulturu i društvena pitanja, Udruga građana „Dijalog”, Mostar, br. 14, str. 63 - 72.

- Eliade, Mircea (2006) Slike i simboli, Fabula nova, Zagreb.

- GLūCK LeOpold (1889) „Tetoviranje kože kod katolika u Bosni i Hercegovini", Glasnik zemaljskog muzeja, Zemaljski muzej, Sarajevo, br. 3, str. 81 - 88. (Rad je izvorno objavljen na njemačkome jeziku: „Die Taetowierung der Haut bei den Katholiken Bosniens und der Herzegowina", Wissenschaftliche Mitteilungen aus Bosnien und Herzegowina, sv. II, Wien, 1884.)

- Herceg, Toni (2017) „Tetovaže katolika u srednjoj Bosni, simbolički ornament duha i tijela", Hum, Sveučilište u Mostaru, Filozofski fakultet, Mostar, god. XII, br. 17 - 18, str. 342 - 367 .

- KošćaK, Silvio, (2017) „Kenoza križa - forma i sadržaj svjedočanstva suvremenih Kristovih svjedoka, Promišljanja na tragu Hansa Ursa von Balthasara“, Diacovensia: teološki prilozi, Katolički bogoslovni fakultet u Đakovu, Đakovo, god. XXV, br. 4, str. $617-637$

- Petrić, Mario (1972) Običaji tatauiranja kod balkanskih naroda - Karakteristika, uloga i porijeklo, doktorska disertacija, Filozofski fakultet, Sarajevo

- Petrić, Mario (1966) „On Tattooing and Cicatrization in Prehistoric population of a Part of Balkans - O pitanju tatauiranja i cikatrizacije kod prethistorijskog stanovništva jednog dijela Balkana“, Godišnjak Centra za balkanološka istraživanja, Akademija nauka i umjetnosti BiH, Sarajevo, knj. 4 (2). 
- Ravasi, Gianfranco - Dal Covolo, Enrico (2012) Comunicare la fede. Per una nuova evangelizazione, Lateran University Press, Vatikan.

- Sanders, Clinton - Vail, Agnus (2008) Customizing the Body: The Art and Culture of Tattooing, Temple University Press, Philadelphia.

- StipČević, Aleksandar (1974) Iliri, Školska knjiga, Zagreb.

- Truhelka, Ćiro (1894) „Tetoviranje Hrvata Katolika u Bosni i Hercegovini“, Glasnik zemaljskog muzeja u Bosni i Hercegovini, Zemaljski Muzej, Sarajevo, 6 (travanj-lipanj), str. 241 - 257.

- Vuletić Vukasović, Vid (1894) „Sicanje Hrvata (tetoviranje-tatuaž) u Herceg-Bosni“, Bosanska vila, Sarajevo, <http://look-into-my-face.blogspot.com/>, (5. V. 2020.).

- Wilson, SARAh (2008) Marks of identity: the performance of tattoos among women in contemporary American society, magistarski rad, University of Maryland, Maryland. 
Preliminary communication

Received on October 28, 2020

Accepted on April 11, 2021

Vesna Haluga - NiKša Sviličić

University North, Varaždin/Koprivnica

\section{RESEARCH OF CONTEMPORARY PERCEPTION OF TRADITIONAL TATTOOS ON THE EXAMPLE OF TATTOOS OF CATHOLIC WOMEN FROM BOSNIA AND HERZEGOVINA}

\section{Abstract}

The paper deals with tattoos of Catholic women from Bosnia and Herzegovina, function of the tattoo from the identity, religious and communication aspect, primarily as a means of non-verbal visual communication as well as its contemporary perception. The traditional/religious tattoo on the example of tattooed Catholic women from $\mathrm{BiH}$, which is the subject of this research, represents a conscious bodily modification historically conditioned by the environment and culture. The paper studied perception of traditional/religious tattoos taking into consideration the fact that more than $90 \%$ of the population of the Republic of Croatia are declared believers and whether a person with a tattooed religious symbol is a believer, or whether that person is perceived as a believer because of a tattooed religious symbol/sign. The paper also discusses the possibility of traditional tattoos contribution to the process of new evangelization. The research was conducted on a sample of 310 respondents, and the aim of the research is to determine the perception of religious/traditional tattoos, i.e. whether they are influenced by sociodemographic characteristics, whether it is generally acceptable or declared believers have a more positive attitude and can the traditional tattoo be a communication symbol of declared believers.

Keywords: tattoo; traditional/religious tattoo; communication; new evangelization; perception 